УДК 502:33

\title{
M. A. Iванicoвa,
}

аспірант кафедри регіональної політики, Навчально-науковий інститут

публічного управління та державної служби Київського Начіонального

університету імені Тараса Шевченка, м. Київ

ORCID ID: 0000-0002-7185-2388

DOI: $10.32702 / 2306-6814.2021 .18 .115$

\section{ОСНОВНI ІМПЕРАТИВИ СПІВРОБІТНИЦТВА УКРАЇНИ 3 МІЖНАРОАНИМИ ОРГАНІЗАЦІЯМИ У СФЕРІ

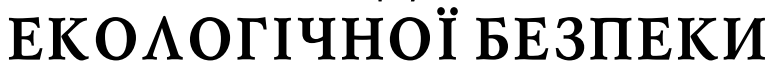

\author{
M. Ivanisova, \\ Postgraduate student of the Department of Regional Policy, Educational and Scientific Institute \\ of Public Administration and Civil Service Taras Shevchenko National University of Kyiv, Kyiv
}

MAIN IMPERATIVES OF UKRAINE'S COOPERATION WITH INTERNATIONAL ORGANIZATIONS IN THE FIELD OF ECOLOGICAL SAFETY

У статті надано характеристику співробітництва України з міжнародними організаціями у сфері екологічної безпеки, розглянуті основні вектори та заходи, що забезпечують міжнародне співробітництво у зазначеному напрямі. Вказані сентенції займають важливе місце у зовнішньополітичному курсі держави, оскільки багато екологічних проблем носять міждержавний. транскордонний і навіть глобальний характер, пов'язані н лише екологічними, а й економічними зв'язками, визначають умови функціонування кожної людини і країни загалом.

Узагальнено основні рівні та напрями, що забезпечують міжнародне співробітництво у сфері екологічної безпеки. Це дало змогу дослідити готовність держав світу до стимулювання енерго- і ресурсозбереження, структурної перебудови економіки задля суттєвого зменшення рівня забруднення довкілля, посилення екологічної безпеки.

Розвиток ключових імперативів співробітництва України з міжнародними організаціями направлений на узгодження вітчизняного законодавства з європейськими стандартами, пропагування раціонального використання природних ресурсів у контексті забезпечення екологічної безпеки.

International cooperation in the field of ecological safety occupies an important place in Ukraine's foreign policy. At the present stage of development, the problem of the relationship between the economic and ecological components determines the conditions of functioning of each person and the state as a whole.

World experience shows that further development of market relations and competition will lead to a significant increase in production, stimulate energy and resource conservation, restructuring of Ukraine's economy, which will significantly reduce the level of environmental pollution.

Cooperation with international organizations will contribute to the expansion of Ukraine's experience, the creation of the necessary legal framework and the renewal of public administration mechanisms in the field of ecological safety. The key forms of international cooperation in the field of environmental protection, rational use of natural resources in the context of ecological safety are revealed. One of the main forms of international cooperation in environmental problems solving is the conclusion of treaties and other types of international agreements that are used to coordinate environmental measures in different countries. Participants in bilateral and multilateral agreements and international conventions are states that have common problems or interests.

It is established that the activities of internationalorganizations, commissions and unions are aimed not only at solving global environmental problems of today, but also requires international efforts to 
study and analyze the root causes of the crisis, combat its consequences, involve the general public, provide legal regulation and invest in future. The priority directions of activity of the association Ukraine - the European Union are defined.

Improving international cooperation in the field of greening the economy, education, environmental law and environmental policy - new aspects of the scientific concept of ecological safety, which determine the importance of implementing progressive cooperation of international economic relations in the interests of: creating effective mechanisms for ecological safety and responsibility; environmental aggression and expansionism; prevention of new types of environmental threats in space and time; development of international cooperation in the field of environmental and environmental activities; introduction of eco-technologies, optimization of the structure of exports and imports of countries taking into account the environmental effects of international liberalization.

Ключові слова: міжнародні організації, екологічна безпека, захист довкілля, сВітовий досВід, природоохоронні заходи, міжнародне співробітниитво.

Key words: international organizations, ecological safety, environmental protection, environmental measures, world experience, international cooperation.

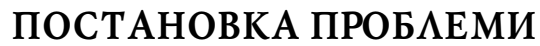

\section{У ЗАГА ІЗ ВАЖАИВИМИ НАУКОВИМИ ЧИ \\ ПРАКТИЧНИМИ ЗАВААННЯМИ}

На сьогодні у глобальному світі спостерігається значна еколого-економічна криза, зумовлена підвищеним рівнем концентрації промислового виробництва та сільського господарства, нераціональним використанням природних ресурсів, нарощуванням продуктивних сил. Усе це носило переважно споживацький характер використання та відбувалось без урахування екологічних наслідків. Недостатньо уваги приділялося й управлінню охороною природи та контролю за якістю природного середовища [10, с. 70-73].

Наразі екологічна ситуація, яка склалася в Україні, потребує активного втручання органів публічної влади та суб'єктів господарювання у сферу екологічної безпеки, підвищення технології виробництва з метою зниження шкідливих викидів в атмосфреру і гідросфреру, впровадження виробництва замкнутого циклу, запровадження інноваційних технологій задля екологізації виробництва. Звичайно, усього цього можна досягти за наявності достатнього фрінансового забезпечення щодо проведення відповідної екологічної політики органів публічної влади, підприємств, громадськості, спрямованої на заощадження природної спадщини України, а також розвитку співробітництва нашої держави з міжнародними організаціями у сорері екологічної безпеки.

Існуючі підходи до осмислення перспектив людства все більше розглядаються з точки зору екологічної безпеки, її визначення крізь призму всеосяжного та багатоаспектного наукового значення, одночасно детермінуючи та інтегруючи політичні, економічні, правові, інформаційні, інноваційні, ідеологічні та культурні процеси [4, с. 211].

Україна, як і інші країни світу, перебуваючи в єдиній взаємозалежній природній системі Європи, не може відсторонитися від проблем забруднення і руйнування біосфери на континенті. Тому співробітництво з міжна- родними організаціями у сфері екологічної безпеки та світовий досвід забезпечення сталого розвитку відкривають нові можливості та вказують на необхідність комплексного підходу до вирішення означених проблем.

\section{AHA $\Lambda$ I3 OCT AHHIX AOC $\Lambda$ IAЖEHЬ I ПУБАІКАЦІЙ, В ЯКИХ ЗАПОЧАТКОВАНО

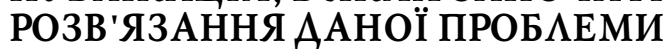

Висвітленню різних аспектів екологічної безпеки та наслідків екологічних проблем присвячені наукові доробки вітчизняних та зарубіжних учених: Н. Арбатової, Г. Білявського, А. Бохана, К. Величко, Л. Гладкої, В. Глушкова, Л. Грицак, В. Джигирей, Ю. Злобіна, А. Кокеева, С. Макар, М. Падуна, Т.Сафранової, В. Сторожук, К. Толоки, А. Шаляпіна, Р. Яцюк та ін.

Однак невирішеними залишаються питання визначення особливостей співпраці України з міжнародними організаціями у сфері екологічної безпеки, вироблення стратегії збереження та охорони навколишнього природного середовища. Тому ця тема $є$ надзвичайно актуальною та потребує подальших наукових розвідок.

\section{META CTATTI}

Метою статті $€$ визначення основних імперативів співробітництва України з міжнародними організаціями у сорері екологічної безпеки.

\section{ВИК ААА ОСНОВНОГО МАТЕРІААУ АОС АІАЖЕННЯ 3 ПОВНИМ ОБГРУНТУВАННЯМ ОТРИМАНИХ

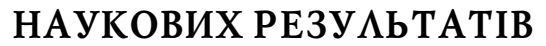

Екологічні проблеми почали обговорюватися світовою спільнотою у 60-ті рр. XX ст. Це пов'язано передусім з тим, що питання включення захисту навколишнього середовища в соціальне і економічне планування потребувало врахування довгострокової здатності природних екосистем забезпечувати існування населення. Формування сучасної системи співробітництва міжнародних організацій із урядами країн світу у сфрері охо- 
рони навколишнього середовища проходило поступово і характеризується за чотирма рівнями такого співробітництва, зокрема: розширення обміну досвідом; розробка і здійснення заходів із охорони елементів природного середовища; наростання зусиль усіх країн світу у вирішенні завдань охорони довкілля; розробка і здійснення глобальних природоохоронних заходів. Для реалізації останніх, на першій Конференції ООН із прав людини у 1968 р. міжнародне співтовариство визнало взаємозалежність світу і прав людини, в тому числі право на життя. А вже у 1972 р. Стокгольмська конференція $\mathrm{OOH}$ із навколишнього середовища ознаменувала початок найважливішого етапу щодо екологічної політики держав і міжнародних співтовариств. За підсумками цієї конференції була прийнята Декларація, в якій визначалися стратегічні цілі та напрями дій світової спільноти у сорері екологічної безпеки.

Пізніше на Віденській конференції 1985 р. погоджено багатосторонню екологічну угоду (Віденська конвенція про охорону озонового шару), яка вступила в дію з 1988 р. і була направлена на забезпечення співпраці між країнами світу задля проведення систематичних спостережень, досліджень і обміну інформацією, задля більш глибоко зрозуміти й оцінити вплив людства на озоновий шар і оцінити наслідки антропогенного навантаження на здоров'я людини і довкілля.

Сьогодні глобальна екологічна криза, а точніше реальна небезпека екологічної катастрофи дедалі більше визнається на державному та міжнародному рівнях. Прискорення економічного та науково-технічного розвитку в окремих регіонах світу наприкінці $X X$ ст. спричинило появу центрів стабілізації (північна частина Європи та Азії, північ Канади, Аляска, Південна Америка й Австралія) та дестабілізації (Північно-американський, Європейський та Азійський) навколишнього природного середовища [3, с. 13]. А відтак шлях до екологічної безпеки країн світу простягається через вирішення суміжного стратегічного завдання - здійснення всіма доступними методами господарської діяльності на тій чи іншій території із одночасним збереженням обсягів природної біоти, яка повинна стати центром відновлення природного середовища і біоти в обсязі, необхідному для забезпечення стійкості навколишнього середовища на засадах міждержавного співробітництва із залученням до цього процесу екологоорієнтованих міжнародних організацій.

Нині у світі фрункціонує понад 100 різних міжнародних організацій, що займаються питаннями екологічної безпеки. Найбільш авторитетною серед них міжнародною міжурядовою організацієює Організація Об'єднаних Націй (OOH). Одне з найважливіших напрямів ії діяльності сконцентровано на співпраці в галузі збереження довкілля та охорони навколишнього середовища, проведення міжнародних нарад і конференцій, прийняття та імплементації резолюцій і декларацій, зокрема, Декларації Стокгольмської конференції ООН (1972 р.) і Всесвітньої Хартії природи (1982 г.).

При ООН здійснюють свою діяльність також і спеціалізовані міжнародні організації з охорони навколишнього середовища, серед яких такі інституції, як ВМО (Всесвітня метеорологічна організація), ЮНЕСКО (Організація об'єднаних націй з питань освіти, науки і культури), ВООЗ (Всесвітня організація охорони здоров'я), МАГАТЕ (Міжнародна організація з радіологічного захисту), ММО (Міжнародна морська організація), МСОП (Міжнародна спілка охорони природи та природних ресурсів), МКОДР (Міжнародна комісія з охорони довкілля і розвитку), ЕФОС (Глобальний фонд навколишнього середовища) та інші.

Діяльність міжнародних організацій, комісій та спілок направлена як на вирішення глобальних екологічних проблем сучасності, так і на спрямування міжнародних зусиль на дослідження та аналіз першочергових причин кризи, боротьбу з її наслідками, залучення широкої громадськості до цього процесу, забезпечення засобів правового регулювання та інвестування в майбутнє [6]. Наразі Україна бере активну участь у діяльності міжнародних організацій, які займаються вирішенням глобальних та регіональних проблем охорони навколишнього середовища (ЮНЕП, ЮНЕСКО, ВООЗ та інші).

Відповідно в рамках міжнародного співробітництва розв'язати проблеми навколишнього середовища можна шляхом:

- укладання договорів та інших міжнародних угод, які використовуються для координації природоохоронних заходів у різних країнах. При цьому учасниками двосторонніх і багатосторонніх угод і міжнародних конвенцій виступають держави, які мають спільні проблеми або інтереси [5]. Важливою міжнародною угодою стала Конвенція ООН ("Хартія морів", 1982 р.) з морського права, яка визначає вимоги до охорони морського середовища під час освоєння ресурсів морського дна поза зонами національної юрисдикції. За цією конвенцією держави повинні оберігати морське середовище та захищати його від забруднення [7];

- створення спеціальних фондів, зокрема такого міжнародного незалежного фрінансового суб'єкта, яким $є$ Глобальна екологічна фрундація (ГЕФ), утворена в 1991 р., діяльність якої реалізується через Програму розвитку $\mathrm{OOH}$;

- реалізації програми по навколишньому середовищу ООН і Всесвітнього банку, що надає гранти країнам, які розвиваються, а також країнам із перехідною економікою у сфері екологічної безпеки.

До ключових імперативів співробітництва міжнародних організацій в галузі охорони навколишнього природного середовища, раціонального використання природних ресурсів у контексті забезпечення екологічної безпеки можна віднести:

- створення підгрунтя для забезпечення міжпарламентського співробітництва, наслідком якого $є$ розроблення законодавства і здійснення координації законодавчої діяльності щодо розв'язання глобальних і регіональних екологічних проблем, спільного використання транскордонних природних об'єктів, налагодження взаємодії урядів країн світу для реалізацій міжнародних екологічних програм і проєктів. Міжнародно-правове співробітництво країн дозволить виробити спільні підходи як до попередження та ліквідації негативних наслідків антропогенного впливу на природне довкілля, так і до раціонального природокористування;

- конвенційне регулювання природоохоронної діяльності шляхом укладання договорів, а також інших 
видів міжнародних угод, що передбачає реалізацію єдиного підходу різних країн до вирішення конкретних екологічних проблем;

- налагодження співробітництва окремих країн із міжнародними природоохоронними організаціями для координації спільного проведення природоохоронних заходів (міжнародних екологічних конференцій, форумів тощо);

- залучення громадськості, громадських організацій та приватного сектору до міжнародного екологічного співробітництва;

- збереження природних екосистем;

- створення ефективної системи міжнародної екологічної відповідальності;

- науково-технічне співробітництво, обмін інформацією, знаннями, досвідом та кращими практиками з метою мінімізації антропогенного впливу і раціонального використання природних ресурсів.

Попри такий вагомий перелік форм міжнародної співпраці, їх дієвість $€$ доволі низькою та не знижує ризиків екологічної катастрофи як виду глобальної проблеми людства. У цьому контексті на особливу увагу заслуговують питання убезпечення впливу нової глобальної проблеми людства, а саме пандемії COVID-19 на екологічну складову. Пандемія коронавірусу зачепила практично всі країни світу, негативно вплинула на світову та національні економіки, спричинивши тим самим глибоку економічну та соціальну кризу. Поширення пандемії COVID-19 змінило і поведінкову модель споживання, за якої економічне зростання вже не $є$ основним пріоритетом.

Підтвердженням зазначеної думки є позиція Ю. Маклюк, яка зазначає, що "сповільнення економічної діяльності внаслідок епідемії $є$ як серйозним викликом для охорони довкілля, так і одночасно певною можливістю. Розвиток таких проєктів, як поновлювальна енергетика та стале сільське і лісове господарство, не тільки зменшують шкоду для довкілля, а й створюють більше робочих місць" [9]. І в цьому контексті значущу роль відіграють міжнародні організації. Основні напрями діяльності останніх у сорері міжнародного співробітництва полягають у розвитку міжнародного партнерства, підготовки обгрунтувань щодо приєднання України до багатосторонніх договорів, зміцнення двостороннього співробітництва, розширення взаємозв'язків із міжнародними міжурядовими організаціями і фрінансовими інститутами, розробці дво- і багатосторонніх угод із прикордонними державами, різними країнами Європи і Азії, реалізації домовленостей в рамках підписаних угод.

Кожна угода $є$ унікальним документом, має свій власний незалежний правовий статус і вимагає прийняття країною необхідних заходів щодо забезпечення більш суворого виконання і дотримання законів, норм, політики та ініціатив. Так, зокрема, Україна долучилася до Всесвітньої зустрічі глав держав та урядів в Ріо-деЖанейро у 1992 р. та Йоганнесбурзі у 2002 р., де були підписані програмні документи, які реалізуються сьогодні на національному рівні [2]. Найважливішими досягненнями конференції ООН у Ріо-де-Жанейро у 1992 р. було визнання того, що: проблема охорони навколишнього середовища і економічний розвиток не можуть розглядатися окремо (принцип 4); держави повинні співпрацювати на засадах всесвітнього партнерства з метою збереження, захисту і відновлення здоров'я й цілісності екосистеми Землі (принцип 7); світ, розвиток і захист навколишнього середовища взаємопов'язані і нероздільні (принцип 25). Принцип відповідального підходу до навколишнього середовища, закріплений в Декларації, наголошує: в цілях захисту навколишнього середовища держави в залежності від своїх можливостей повсюдно застосовують принцип відповідальності за наслідки діяльності людини [2].

Починаючи з 1995 р., Україна за підтримки міжнародних організацій бере участь у роботі Європейської Економічної комісії як повноправний член Ради Європи однієї з найвпливовіших організацій, діяльність якої направлена на охорону навколишнього середовища. Водночас наша держава як член $\mathrm{OOH}$, долучилася до міжнародних конвенцій та підписала двосторонні міжнародні угоди із сусідніми країнами - Білоруссю, Грузією, Молдовою, Словаччиною, Польщею та ін. в екологічній сфрері, а також з країнами дальнього зарубіжжя - Австрією і Фінляндією, Ізраїлем, Данією, Нідерландами, США. Це є свідченням трансгенераційної відповідальності, що характеризується розбудовою інституту відповідальності за збереження природи як єдиного цілого для прийдешніх поколінь.

Крім універсальних міжнародних організацій, проблемами екологічної безпеки займається значна кількість регіональних організацій загальної і спеціальної компетенції. У цьому зв'язку заслуговує на увагу, Маастрихтський договір про Європейський Союз, що закріплює природоохоронні цілі цієї організації, зокрема такі з них, які направлені на врегулювання на міжнародному рівні заходів, що належать до регіональних і загальносвітових проблем навколишнього середовища.

У сучасній системі міжнародних відносин визначилась тенденція щодо перерозподілу функцій між суб'єктами світової політики. Зокрема, зростає значуща роль недержавних (неурядових) організацій, які не тільки впливають на світовий політичний процес як у глобальному, так і в регіональному вимірах, а й здійснюють безпосередній тиск на уряди країн світу, контролюють виконання міжнародних угод, у тому числі екологічних. Серед найбільш впливових недержавних (неурядових) організацій у досліджуваній сфері прийнято вважати Всесвітній фронд дикої природи (WWF), Всесвітнє товариство захисту тварин (WSPA), Грінпіс (Greenpeace), Міжнародний зелений хрест (Green Cross), Міжнародний союз охорони природи (IUCN) та ін.

Загалом екологічну безпеку не можна забезпечити повністю в одній окремо взятій країні. Для її досягнення необхідним $є$ налагодження міждержавного, міжрегіонального та транскордонного співробітництва за обов'язкової підтримки міжнародних організацій. Оскільки переважна більшість країн світу в основному вже зруйнували своє природне середовище і наразі $є$ головними екологічними забруднювачами. У цьому сенсі показовим є ухвалення Карпатської конвенції, покликаної сприяти збереженню найбільшого в Європі заповідника дикої природи, оточеного горами як одного з важ- 
ливих векторів подальшого екологічного розвитку для країн Східної Європи [8].

Враховуючи вищевикладене, можна стверджувати, що проблеми екологічної безпеки $є$ за своєю природою міжнародними, вирішення яких направлене на подальше покращення якості життя людства і виявляється можливим у межах стабільного соціально-економічного розвитку, не руйнує природний біотичний механізм саморегуляції природи. В інтересах міжнародного співтовариства екологічні організації $€$ вагомим рушійним суб'єктом відстоювання екоінтересів, адже здатні впливати як на прийняття урядових рішень, так і на гармонізацію суспільних відносин у контексті сталого розвитку.

\section{ВИСНОВКИ 3 ПРОВЕАЕНОГО АОСАІАЖЕННЯ І ПЕРСПЕКТИВИ

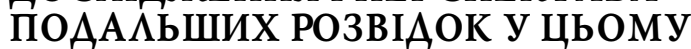 НАПР ЯМ}

Отже, для майбутнього процвітання людської цивілізації, об'єктивно необхідною є екологізація усіх видів і форм міжнародних відносин, що вимагає запровадження на глобальному рівні системи ефективного управління, яка функціонуватиме на основі екологічного імперативу. Розв'язання сучасних екологічних проблем можливе тільки в умовах широкого й активного співробітництва всіх держав світу з міжнародними організаціями у цій сфрері. Оскільки окрім забезпечення подальшого екологічно стійкого соціально-економічного стану як цивілізації загалом, так і кожної держави окремо, вкрай важливим стає питання створення платорорми для інноваційного екологічного світогляду і формування нового підходу до природи як до загального надбання всієї нації на засадах міжнародного співробітництва.

Література:

1. Арбатова Н.К., Кокеев А.М. Співробітництво України та ЄC в сорері охорони довкілля. URL: http:// lib.znate.ru/docs/index-272010.html?page=3 (Дата звернення: 30.08.2021).

2. Білявський Г.О., Падун М.М. Екологія: підруч. К.: KHEУ, 2005. $371 \mathrm{c}$.

3. Бохан А.В. Идеи глобального эволюционизма в понимании экологической безопасности. Науковий огляд. 2014. № 2. С. 13-21.

4. Величко К.Ю., Толок К.О. Екологічна криза як найбільший виклик світовій безпеці в умовах глобалізації. Механізми забезпечення сталого розвитку економіки: проблеми, перспективи, міжнародний досвід: матеріали I Міжнар. наук.-практ. конф., 23 квітня 2020 р. / редкол.: О.І. Черевко та ін.; Харківський держ. ун-т харч. та торг. Х.: ХДУХТ, 2020. 277 с. С. 211.

5. Глушкова В.Г., Макар С.В. Экономика природопользования: учебное пособие. М.: Гардарика, 2007. 448 с.

6. Грицак Л.Р. Міжнародне екологічне право i співробітництво України в екологічній сорері. URL: http:/ / studentam.net.ua/content/view /5849/129 / (Дата звернення: 30.08.2021).

7. Джигирей В.С., Сторожук В.М., Яцюк Р.А. Основи екології та охорони навколишнього природного середовища. Екологія та охорона природи: навч. посіб. 2-ге вид., доп. Львів: Афріша, 2004. 272 с.
8. Злобін Ю.А., Сафрранов Т.А. Екологічні основи природокористування: навч. посіб. 3-тє вид., стереот. Львів: Новий Світ-2000, 2006. 248 с.

9. Не паніка, а здоровий глузд. Чому карантин можливість навчитися жити екологічно. Коронавірус рятує нас від глобального потепління? Як пов'язані карантин і довкілля. URL: https://www.thevillage.com.ua/ village/city/eco/295669-yak-koronavirus-vplivae-naekologiyu (Дата звернення: 30.08.2021).

10. Світовий досвід та співробітництво України у сорері охорони навколишнього середовища / Л.І. Гладка, А.С. Шаляпіна / / Культура народов Причерноморья. 2013. № 254. С. 70-73.

\section{References:}

1. Arbatova, N.K. and Kokeev, A.M. (2010), "Cooperation between Ukraine and the EU in the field of environmental protection", available at: http://lib.znate.ru / docs/index-272010.html?page =3 (Accessed 30 Aug 2021).

2. Biliavs'ky,j H.O. and Padun, M.M. (2005), Ekolohiia [Ecology], KNEU, Kyiv, Ukraine.

3. Bokhan, A.V. (2014), "Ideas of global evolutionism in understanding environmental safety", Naukovyj ohliad, vol. 2, pp. 13-21.

4. Velychko, K.Yu. and Tolok, K.O. (2020), "The ecological crisis as the greatest challenge to world security in the context of globalization", Mekhanizmy zabezpechennia staloho rozvytku ekonomiky : problemy, perspektyvy, mizhnarodnyj dosvid : materialy I Mizhnar. nauk.-prakt. konf. [Mechanisms for ensuring sustainable economic development: problems, prospects, international experience: materials of the First International Scientific and Practical Conference], KhDUKhT, Kharkiv, Ukraine, 23 april, p. 211.

5. Hlushkova, V.H. and Makar, S.V. (2007), Ekonomyka pryrodopol'zovanyia [Economics of environmental management], Hardaryka, Moscow, Russia.

6. Hrytsak, L.R. (2016), "International environmental law and cooperation of Ukraine in the environmental sphere", available at: http://studentam.net.ua/content / view /5849/129/(Accessed 30 Aug 2021).

7. Dzhyhyrej, V.S. Storozhuk, V.M. and Yatsiuk, R.A. (2004), Osnovy ekolohii ta okhorony navkolyshn'oho pryrodnoho seredovyscha. Ekolohiia ta okhorona pryrody [Fundamentals of ecology and environmental protection. Ecology and nature protection], Afisha, Lviv, Ukraine.

8. Zlobin Yu.A. and Safranov T.A. (2006), Ekolohichni osnovy pryrodokorystuvannia [Ecological bases of nature management], Novyj Svit-2000, Lviv, Ukraine.

9. The Village (2020), "Not panic, but common sense. Why quarantine is an opportunity to learn to live ecologically. Does the coronavirus save us from global warming? How quarantine and the environment are related", available at: https://www.thevillage.com.ua/ village/city/eco/295669-yak-koronavirus-vplivae-naekologiyu (Accessed 30 Aug 2021).

10. Hladka, L.I. and Shaliapina, A.S. (2013), "World experience and cooperation of Ukraine in the field of environmental protection", Kul'tura narodov Prychernomor'ia, vol. 254, pp. 70-73.

Стаття надійшла до редакиї 07.09.2021 p. 